Original Research Paper

\title{
Manufacturing Strategy and Competitive Advantage: A Mediating role of Organizational Culture (A Case Study of Small Industry Batik Trusmi Indonesia)
}

\author{
${ }^{1}$ Aam Amaningsih Jumhur, ${ }^{2}$ Nik Hasnaa Nik Mahmood and ${ }^{3}$ Muchdie \\ ${ }^{1}$ Department of Mechanical Engineering Education, Universitas Negeri Jakarta, Indonesia \\ ${ }^{2}$ Razak School of Engineering and Advance Technology, \\ Universiti Teknologi Malaysia, Kuala Lumpur, Malaysia \\ ${ }^{3}$ Department of Management, Post Graduate School, \\ Muhammadiyah University of Prof. DR. Hamka, Jakarta, Indonesia
}

Article history

Received: 17-02-2017

Revised: $18-03-2017$

Accepted: 17-07-2017

Corresponding Author: Aam Amaningsih Jumhur Department Mechanical Engineering Education, Universitas Negeri Jakarta, Indonesia

Email: aamamaningsihjumhur@unj.ac.id

\section{Introduction}

Trusmi batik is produced by a small industry in Cirebon Regency, Indonesia on the basis of culture and tradition and made of raw material available in the country so that this product has a cultural value. This batik industry absorbs massive workforce and increases community empowerment because it has involved a number of small and medium even micro scale enterprises comprising a number of home industries.

Trusmi batik center has had 416 small industries and 3,324 batik makers with the following composition of age group: 143 Makers age 0-20; 932 makers age 21-40; 2,116 makers age 41-60; 133 makers age 61-80.

A small scale batik industry has shown its possibility to improve marketing performance by means of competitive advantage which can be created by conducting product innovation (Wibowo, 2006). Several industries consider some crucial resources i.e., workforce, network, reputation, culture and marketing (Abdul Kareem, 2009). Marketing skill is essential to ensure that every batik product created can meet market demand.

Manufacturing strategy is defined as a dimension that company product system has to possess in support of the market demand where the company plunges into competition (Krajewski and dan Ritzman, 2002). General theme in manufacturing strategy research is to describe company's option on the importance of capabilities of or competitive priorities for a company. Some researchers consider that manufacturing strategy represents competitive priorities (Leong et al., 1990; Burgess et al., 1998).

This study strives to see the effect of manufacturing strategy toward competitive advantage. It is expected that result of the study can be an alternative solution of 
the company to explore competitive advantage resources. Manufacturing strategy on one side directly affects competitive advantage in addition to giving effect to the competitive advantage mediated by organizational culture on the other side. This study aims to investigate the effect of organizational culture mediation toward the correlation between manufacturing strategy and competitive advantage on Indonesia's Batik Trusmi industry.

Indonesia's Trusmi batik small industry has been selected as the subject of the investigation. This is due to the fact that batik business has competitive advantage strategy and similar background to previously mentioned problem.

Trusmi batik is one of the SMEs from the largest Batik products in Cirebon, West Java Indonesia. Producing batik is one of the main livelihoods; therefore batik Trusmi classified into intensive labor industry since requires a lot of human resources with some special skills. Batik industry is an industry that based on culture and tradition with the raw materials available in the country and has a cultural value, to absorb a lot of labor and increase community empowerment and consists of many medium and small businesses even in micro size of domestic industry. As the industry based on culture and tradition, batik Cirebon industry is a business hereditary has been known since the 14th century and continues to develop into the people's livelihood. Batik industry is an excellent product from Indonesia which has the economic potential and competitiveness should be developed and improved

\section{Literature Review}

\section{Perception of Correlation between Manufacturing Strategy and Competitive Advantage}

Skinner defines manufacturing strategy as a process of complex and dynamic decision making. It is complex as the decision on one assignment and activity in manufacturing area must be congruent and aligned with corporate decision or other functions such as finance or marketing. In addition, it is dynamic as it must be able to adjust with the existing changes occurring in the environment (Skinner, 1969).

Miller and Roth (1994) emphasizes on two essential elements of manufacturing strategy Skinner (1969) noted. They are manufacturing task and pattern of manufacturing choice. Manufacturing task is defined as manufacturing capabilities used to achieve and maintain competitive position the company has set as a target. Skinner (1969); Wheelwright and Hayes (1985); Ferdows et al. (1990) as well as Ward and Duray (2000) emphasize on low production cost, product quality and performance, flexibility, product delivery and innovation level as five critical capabilities in manufacturing field.
Manufacturing issues in new era covers lead time reduction to satisfy customer, faster new product introduction, flexibility to adapt and market change, product quality improvement, cost reduction and customer service. Under particular condition, it is unavoidable to have technology play its role in order to meet high performance in business. Therefore, this urges a company to adopt the technology and take benefit from it. Some reasons as to the adoption may often relate to cost reduction, flexibility improvement, product quality improvement and reduction in consideration i.e., the importance of implementing a control, management competitiveness in the market and supplier independence (Small and Chen, 1995).

Manufacturing strategy can be regarded as a pattern of selection made to meet complete competitive advantage of one business unit. This strategy is either explicitly set or implicitly realized in a real time decision flow at different time slots. The writer is trying to explain the importance of characteristic in terms of manufacturing strategy based on conceptual perspective and to outline patterns of strategic decision resulted from types of structure and infrastructure of the company organization.

There have been a numerous studies in manufacturing strategy addressing issues about environmental and organizational culture. A study by Amoako-Gyampah and Acquaah (2008) titled Manufacturing Strategy, Competitiveness Strategy and Organization Performance: An Empirical study in the environment of developing economic: This study reviews a correlation between manufacturing and competitive advantage strategy and examines the effects of those strategies toward organizational performance in Ghana's manufacturing organization. This study reveals a significant and positive correlation between strategy of competition and of manufacturing strategy on cost, delivery, flexibility and quality. Findings also reveal that quality has become the only component of manufacturing strategy that affects performance. The following decision shows that competitiveness strategy indirectly affects organizational performance and it indirectly affects quality too. Thus, an organization may select to try either cost leadership or differentiation strategy focusing on quality that gives the most benefit for organizational performance. Focus on quality provides a way in which an organization is able to reduce the effect of increasing competition resulting from economic reformation in manufacturing environment.

\section{Perception of Correlation between Organizational Culture Competitive Advantage}

Organization is the most important component in a company to figure out elements of organizational culture so that we can make use of them as a strength and competitive advantage. An organizational culture analysis is a complex analysis and expected to promote 
company performance and competitive advantage (Adriana et al., 2012). Yazdani (2013) in his study stated that organizational culture is motivation which successfully creates resources of competitive advantage (Lado and Wilson, 1994). In addition, organizational culture minimizes unclear and uncertain strategic decision of an organization and promotes organizational performance (Jones, 1983). Organizational culture also allows reducing transaction cost involved in preparing human resources (Williamson, 1981). The organization must be able to understand what is unique and rare about its culture that serves as competitive advantage over other competitors and to strengthen cultural elements to generate a good performance of the company.

A culture is not a static entity, it continues to progress due to organizational changes that bring about environmental and other changes. If a culture is an ending product of social interactions of organization members, the management has to try to manipulate the organizational symbol, myth and logo in relation to the organizational culture as a whole. An anthropologist considers the culture as an artifact shaped by collective meanings meanwhile the symbol is created from social interactions. Organizational values perceived and social life context of all members of the organization must be interpreted in order to see the culture as an exogenous element of the organization.

Organization in similar context can be regarded as a source of strength of a company consisting of knowledge, skill, competence, relation and values concerning workers and identified as "organization capital" (Prescott and Visscher, 1980).

Organizational culture refers to the characteristic of the organization instead of the individual who plays as a member. When compared to human, organizational culture is a personality of the organization. Yet, the culture has shaped organizational behavior of the member, further it frequently shapes the member as an individual. Organizational culture can be a source of continuous competitive advantage (Wibowo, 2006).

\section{Research Design}

Three statistic analysis instruments were employed in this study, they are (1) correlation analysis, (2) simple linear regression analysis and (3) multiple linear regression. This multiple linear regression was used because it met the objective of the study that was to investigate the effect of mediation in organizational culture toward the correlation between manufacturing strategy and competitive advantage in Indonesia's Trusmi Batik industry.

\section{Sampling Data Collection}

There are 416 of Small Industries in centers of Small Industries Trusmi Batik Cirebon regency, Indonesia. All the 200 respondents in this study are small batik industry entrepreneurs, contained 131 male respondents and 69 female. This study using accidental sampling as respondents sampling method is based on spontaneity factors, means anyone who accidentally meet investigators and in accordance with the characteristics, then the person can be used as a sample (respondents). By using Slovin's formula (Sevilla, 1960), this research specifies the number of samples, as fallow:

$$
\begin{aligned}
& \mathrm{N}=\mathrm{N} /\left(1+\mathrm{N}^{2}\right) \\
& \mathrm{N}=416 /\left(1+416 \times 0,05^{2}\right) \\
& \mathrm{N}=204
\end{aligned}
$$

Questionnaires were distributed to 204 respondents, but only 200 questionnaires were returned.

\section{Model of Correlation between Manufacturing Strategy and Competitive Advantage and Organizational Culture as Mediator Variable}

Correlation between variables in this study can structurally be seen in Fig. 1.

Figure 1 shows a basic concept concerning paired variable formulated that is correlation between manufacturing strategy and competitive advantage and organizational culture as mediator variable. Testing the condition can be conducted by figuring out the value of correlation coefficient between pairs of variable. The result of correlation test can be seen in Table 1 .

The test shows that correlation coefficient on respective column has significant values in terms of statistics. Significance level generally has high category. This indicates that the paired test is necessary to conduct for every condition to test the role of mediator variable (organizational culture) by means of partial regression analysis based on modeled paired variable.

Correlation between Manufacturing Strategy and Competitive Advantage and Organizational Culture as Mediator Variable

\section{Regression Analysis of Manufacturing Strategy and Competitive Advantage}

Result of regression analysis of manufacturing strategy and competitive advantage can be seen in the following tables.

Table 2 shows that the correlation value between manufacturing strategy and competitive advantage variables is 0.425 which is considered fairly high. The reliability level of regression model is 0.176 (Adjusted coefficient of determination $\mathrm{R}^{2}$ ). It means that $17.6 \%$ varied data of competitive advantage variable can be explained by manufacturing strategy. Significance level in the correlation between manufacturing strategy and competitive advantage variables is shown in the following ANOVA table (Table 3). 


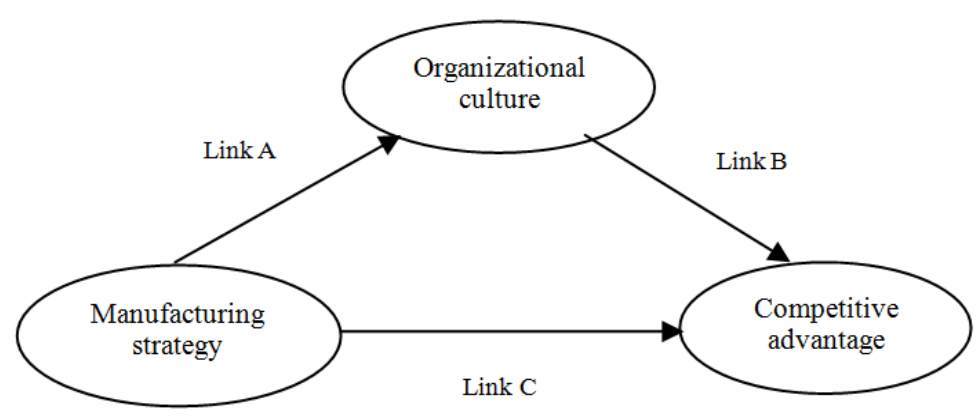

Fig. 1. Correlation between manufacturing strategy and competitive advantage and organizational culture as mediator variable

Table 1. Correlation of manufacturing strategy, organizational culture and competitive advantage

\begin{tabular}{llccc}
\hline & & Manufacturing strategy & Organizational culture & Competitive advantage \\
\hline Manufacturing strategy & Pearson correlation & 1.000 & $0.460^{* *}$ & $0.425^{* *}$ \\
& Sig. (2-tailed) & & 0.000 & 0.000 \\
& N & 192.000 & 192.000 & 192.000 \\
Organizational culture & Pearson correlation & $0.460^{* *}$ & 1.000 & $0.384^{* *}$ \\
& Sig. (2-tailed) & 0.000 & & 0.000 \\
& N & 192.000 & 192.000 & 192.000 \\
Competitive advantage & Pearson correlation & $0.425^{* *}$ & $0.384^{* *}$ & 1.000 \\
& Sig. (2-tailed) & 0.000 & & 192.000 \\
\hline
\end{tabular}

**. Correlation is significant at the 0.01 level (2-tailed)

Table 2. Summary of regression of manufacturing strategy and competitive advantage

\begin{tabular}{lllll}
\hline Model & $\mathrm{R}$ & $\mathrm{R}$ square & Adjusted R square & Std. error of the estimate \\
\hline 1 & $0.425^{\mathrm{a}}$ & 0.18 & 0.176 & 5.20251
\end{tabular}

a. Predictors: (Constant), Manufacturing strategy

Table 3. ANOVA of manufacturing strategy and competitive advantage

\begin{tabular}{llllll}
\hline Model & Sum of squares & df & Mean square & F & Sig. \\
\hline 1 Regression & 1132.68 & 1 & 1132.68 & 41.849 & $0.000^{\mathrm{b}}$ \\
Residual & 5142.57 & 190 & 27.066 & & \\
Total & 6275.25 & 191 & & & \\
\hline
\end{tabular}

a. Dependent variable: Competitive advantage; b. Predictors: (Constant), manufacturing strategy

Result of ANOVA test (Table 3) demonstrates that Fcount of regression model is $(\mathrm{F}=41.849)$. This value is significant on the test run with an alpha level of 5. The significance of correlation between manufacturing and competitive advantage variables seen at Table 4 shows that beta coefficient of manufacturing strategy and competitive advantage variables is 0.425 . This value is significant at an alpha level of less than $5 \%$.

It can be concluded based on the result of regression test that there is a significant correlation between manufacturing strategy and competitive advantage variables. This will indicate a correlation between mediator variable (organizational culture) and competitive advantage variable.

\section{Regression Analysis of Organizational Culture and Competitive Advantage}

Result of regression analysis for organizational culture and competitive advantage can be seen in the following table.
Table 5 shows that the correlation value between organizational culture and competitive advantage variables is 0.384 which is considered fairly high. The reliability level of regression model derived is 0.143 (adjusted coefficient of determination $\mathrm{R}^{2}$ ). It means that $14.3 \%$ varied data of competitive advantage variable can be explained by organizational culture. The significance level in the correlation between organizational culture and competitive advantage variables is shown in the following ANOVA table (Table 6).

Result of ANOVA test (Table 6) demonstrates that Fcount of regression model derived is $(\mathrm{F}=32,918)$. This value is significant at an alpha level of less than $5 \%$. The significance level of correlation between organizational culture and competitive advantage variables can be seen in Table 7. It shows that beta coefficient of organizational culture structure and competitive advantage is 0.384 which is significant at an alpha level of less than $5 \%$. 
Table 4. Beta coefficient of correlation between manufacturing strategy and competitive advantage

\begin{tabular}{lccccc}
\hline & Unstandardized coefficients & \multicolumn{2}{c}{ Standardized coefficients } \\
Model & B & Std. Error & Beta & t & Sig. \\
\hline 1 (Constant) & 53.648 & 3.12 & & 17.193 & 0 \\
Manufacturing strategy & 0.35 & 0.054 & 0.425 & 6.469 & 0 \\
\hline
\end{tabular}

a. Dependent variable: Competitive advantage

Table 5. Summary of regression analysis of organizational culture and competitive advantage

\begin{tabular}{lllll}
\hline Model & $\mathrm{R}$ & $\mathrm{R}$ square & Adjusted R square & Std. error of the estimate \\
\hline 1 & $0.384^{\mathrm{a}}$ & 0.148 & 0.143 & 5.30571 \\
\hline
\end{tabular}

a. Predictors: (Constant), Organizational culture

Table 6. ANOVA of organizational culture and competitive advantage

\begin{tabular}{llllll}
\hline Model & Sum of squares & df & Mean square & F & Sig. \\
\hline 1 Regression & 926.6490 & 1 & 926.649 & 32.918 & $0.000^{6}$ \\
Residual & 5348.601 & 190 & 28.151 & & \\
Total & 6275.250 & 191 & & & \\
\hline
\end{tabular}

a. Dependent variable: Competitive advantage

Table 7. Beta coefficient of organizational culture and competitive advantage

\begin{tabular}{|c|c|c|c|c|c|}
\hline \multirow[b]{2}{*}{ Model } & \multicolumn{2}{|c|}{ Unstandardized coefficients } & \multicolumn{3}{|c|}{ Standardized coefficients } \\
\hline & B & Std. Error & Beta & $\mathrm{t}$ & Sig. \\
\hline 1 (Constant) & 50.79 & 4.009 & & 12.668 & 0 \\
\hline Organizational culture & 0.276 & 0.048 & 0.384 & 5.7370 & 0 \\
\hline
\end{tabular}

a. Dependent variable: Competitive advantage

Based on the result of regression test that there is a significant correlation between organizational culture and competitive advantage variables. This indicate a correlation between mediator variable (organizational culture) and competitive advantage variable.

\section{Regression Analysis of Manufacturing Strategy and Organizational Culture}

Result of regression analysis of manufacturing strategy and organizational culture variables can be seen in the following table.

Table 8 shows that the correlation value between manufacturing strategy and organizational culture variables is 0.460 which is considered fairly high. The reliability level of regression model derived is 0.207 (adjusted coefficient of determination $\mathrm{R}^{2}$ ). It means that $20.7 \%$ varied data of organizational culture variable can be explained by manufacturing strategy. The significance level of the correlation between manufacturing strategy and organizational culture variables is shown in the following ANOVA table (Table 9).

Result of ANOVA test (table 9) demonstrates that Fcount regression model derived is $(\mathrm{F}=50.951)$. This value is significant at an alpha level of less than $5 \%$.

The significance level of correlation between manufacturing strategy and organizational culture variables can be seen in Table 10. It shows that beta coefficient of manufacturing strategic and organizational culture is 0.460 which is significant at an alpha level of less than $5 \%$.

Based on the result of regression test that there is a significant correlation between manufacturing strategy and organizational culture variables. This indicate a correlation between mediator variable (organizational culture) and manufacturing strategy variable.

\section{Regression Analysis of Manufacturing Strategy and} Organizational Culture and Competitive Advantage

Result of regression analysis of manufacturing strategy and organizational culture variables and competitive advantage variable can be seen in the following table.

Table 11 shows that the correlation value between manufacturing strategy and organizational culture variables and competitive advantage variable is 0.475 which is considered fairly high. The reliability level of regression model derived is 0.218 (adjusted coefficient of determination $\mathrm{R}^{2}$ ). This value indicates that $21.8 \%$ varied data of competitive advantage variable can be explained by manufacturing strategy and organizational culture as mediator variable. The significance level of correlation between manufacturing strategy and organizational culture variables and competitive advantage variable is shown in the following table

Result of ANOVA test (Table 12) demonstrates that Fcount of regression model derived is $(\mathrm{F}=27.554)$. This value is significant at an alpha level of less than $5 \%$. The significance level of correlation between manufacturing strategy and organizational culture variables and competitive advantage variable can be seen in Table 13. It shows that beta coefficient of manufacturing strategy variable and organizational culture as mediator variable and competitive advantage variable is 0.315 which is significant at an alpha level of less than $5 \%$. 
Table 8. Summary of regression analysis of manufacturing strategy and organizational culture

\begin{tabular}{lllll}
\hline Model & $\mathrm{R}$ & $\mathrm{R}$ square & Adjusted R square & Std. error of the estimate \\
\hline 1 & $0.460^{\mathrm{a}}$ & 0.211 & 0.207 & 7.10866
\end{tabular}

a. Predictors: (Constant), Manufacturing strategy

Table 9. ANOVA of manufacturing strategy and organizational culture

\begin{tabular}{lrrrrl}
\hline Model & Sum of squares & df & Mean square & F & Sig. \\
\hline 1 Regression & 2574.729 & 1 & 2574.729 & 50.951 & $0.000^{b}$ \\
Residual & 9601.271 & 190 & 50.533 & & \\
Total & 12176.000 & 191 & & & \\
\hline
\end{tabular}

a. Dependent variable: Organizational culture

b. Predictors: (Constant), Manufacturing strategy

Table 10. Beta coefficient of manufacturing strategy and organizational culture

\begin{tabular}{llllll}
\hline & Unstandardized coefficients & \multicolumn{2}{l}{ Standardized coefficients } & t & Sig. \\
\hline Model & B & Std. error & Beta & 12.381 & 0 \\
S Constant) & 52.787 & 4.264 & & 7.1380 & 0 \\
\hline
\end{tabular}

a. Dependent variable: Organizational culture

Table 11. Summary of manufacturing strategy and organizational culture and competitive advantage

\begin{tabular}{|c|c|c|c|c|c|}
\hline Model & $\mathrm{R}$ & R square & Adjusted R square & \multicolumn{2}{|c|}{ Std. error of the estimate } \\
\hline 1 & $0.475^{\mathrm{a}}$ & 0.226 & 0.218 & \multicolumn{2}{|c|}{5.07018} \\
\hline \multicolumn{6}{|c|}{ a. Predictors: (Constant), organizational culture, manufacturing strategy } \\
\hline Model & Sum of squares & df & Mean square & $F$ & Sig. \\
\hline 1 Regression & 1416.673 & 2 & 708.337 & 27.554 & $0.000^{b}$ \\
\hline Residual & 4858.577 & 189 & 25.7070 & & \\
\hline Total & 6275.250 & 191 & & & \\
\hline
\end{tabular}

Table 13. Beta coefficient of manufacturing strategy and competitive advantage

\begin{tabular}{llllrl}
\hline & Unstandardized coefficients & \multicolumn{2}{l}{ Standardized coefficients } \\
Model & B & Std. error & Beta & t & Sig. \\
\hline 1 Constant) & 44.57 & 4.088 & & 10.904 & 0.000 \\
Manufacturing strategy & 0.259 & 0.059 & 0.315 & 4.366 & 0.000 \\
Organizational culture & 0.172 & 0.052 & 0.240 & 3.324 & 0.001 \\
\hline
\end{tabular}

a. Dependent variable: Competitive advantage

It can be concluded based on the result of regression test of manufacturing strategy and competitive advantage variables and organizational culture as mediator variable that there is a significant correlation between manufacturing strategy and mediator variables (organizational culture) and competitive advantage variable.

\section{Conclusion}

It can be concluded based on the result of regression test on manufacturing strategy and competitive advantage variables and organizational culture as mediator variable that there is a significant correlation between manufacturing strategy and mediator variables (organizational culture) and competitive advantage variable altogether. This shows that organizational culture is a mediator variable between manufacturing strategy and competitive advantage in Indonesia's batik Trusmi industry.

Result of analysis demonstrates that organizational culture is a mediator variable between manufacturing strategy and competitive advantage in Indonesia's batik Trusmi industry. This shows that there is no a direct effect of manufacturing strategy variable toward competitive advantage variable. Therefore, it is necessary that organizational culture variable be considered in developing competitive advantage variable in Batik Trusmi industry in Indonesia.

The calculation shows positive correlation made by the models. The correlations have been under statistical tests that result a significant correlation. It means that the significant correlation does exist. The result supports Miller and Roth (1994) perspective 
emphasizing on two elements of manufacturing strategy formerly revealed by Skinner (1969). In addition, the result supports Ward and Duray (2000) emphasizing on low production cost, product quality and performance, flexibility, product delivery and innovation level as five critical capabilities in manufacturing field. This empirical study also supports some manufacturing issues i.e. lead-time, reduction to satisfy customer, faster new product introduction, flexibility to adapt and market change, product quality improvement, cost reduction and customer service (Elitan and Lina, 2006).

It means that the significant correlation does exist. The result empirically supports a statement that competitive advantage has been a part to consider in order to create a value for the customers and to generate competitive advantage for the company (Porter, 1990).

\section{Funding Information}

We would like to inform that the funding for construction this paper is from author's own.

\section{Author's Contribution}

Aam Amaningsih Jumhur: Designed the research plan, organized the study, create discussion and contributed to the writing of the article.

Nik Nashnaa Nik Mahmood: Develop the methodology used in this study, correcting references, article review and the literature

M. Muchdie: Contributed the idea, discussion and writing the article

\section{Ethics}

Authors should address any ethical issues that may arise after the publication of this manuscript.

\section{References}

Wibowo, A.R., 2006. Analysis of factors affecting the innovation of products to increase advantage competitive and performance marketing (Studi in industry batik in town district pekalongan). $\mathrm{PhD}$ Thesis, Master of Management University Diponegoro.

Abdul Kareem, S.K., 2009. Towards meeting global demand: The need for modernization in the process of batik. Proceedings of the Business of Batik, Nov. 30-Dec. 1, Kuala Lumpur, MPH Publishing, Selangor, pp: 81-88.

Krajewski, L.J. and L.P. dan Ritzman, 2002. Operations Management: Strategy and Analysis. 6th Edn., Prentice Hall, London.

Leong, G.K., D.L. Snyder and P.T. Ward, 1990. Research in the process and content of manufacturing strategy. Omega, 18: 109-122
Burgess, T.F., H.K. Gules, J.N.D. Gupta and M. Tekin, 1998. Competitive priorities, process innovations and time-based competition in the manufacturing sectors of industrializing economies: The case of Turkey. Benchmark. Quality Manage. Technol., 5: 304-316.

Skinner, W., 1969. Manufacturing-Missing Link in Corporate Strategy. 1st Edn., Harvard Business Review, Boston, pp: 10.

Miller, J.G. and A.V. Roth, 1994. A taxonomy of manufacturing strategies. Manage. Sci., 40: 285-304.

Wheelwright, S.C. and R.H. Hayes, 1985. Competing through manufacturing. Harvard Bus. Rev., 53: 99-109.

Ferdows, K., J.G. Miller, J. Nakane and T.E. Vollmann, 1990. Evolving manufacturing strategies in Europe, Japan and North America: Projections into the 1990s. Int. J. Operations.

Ward, P. and R. Duray, 2000. Manufacturing strategy in context: Environment, competitive strategy and manufacturing strategy. J. Operat. Manage., 18: 123-138.

Small, M.H. and I.J. Chen, 1995. Investment justification of advanced manufacturing technology: An empirical analysis. J. Eng. Technol. Manage., 12: 27-55.

Amoako-Gyampah, K. and M. Acquaah, 2008. Manufacturing strategy, competitive strategy and firm performance: An empirical study in a developing economy environment. Int. J. Product. Econom., 111: 575-592.

Adriana, T., C. Gelmereanua, P. Barua and L. Morara. 2012. Diagnosing organizational culture for SME performance. Proc. Econom. Finance, 3: 710-715. DOI: $10.1016 / \mathrm{S} 2212-5671(12) 00218-3$

Yazdani, N., 2013. Sustainable competitive advantage: Organizational culture and human resource perspective. Proceedings of the 3rd International Conference on Business Management School of Business and Economics University of Management and Technology, (UMT' 13), Lahore, Pakistan.

Lado, A.A. and M.C. Wilson, 1994. Human resource systems and sustained competitive advantage: A competency-based perspective. Acad. Manage. Rev., 19: 699-727.

Jones, W.O., 1983. Organizational culture and identity: Unity and division at work. SAGE.

Williamson, O.E., 1981. The economics of organization: The transaction cost approach. Am. J. Sociol., 87: 548-577.

Prescott, E.C. and M. Visscher, 1980. Organizational capital. J. Polit. Economy, 88: 446-461.

Sevilla, C.G., 1960. Research Methods. 1st Edn., Rex Printing Company, Quezon City.

Elitan, L. and A., Lina, 2006. Operational strategy management theory and research in Indonesia. CV Alfabeta.

Porter, M.E. 1990. Competitive Strategy. 1st Edn., The Free Press, New York, pp: 20. 